\title{
Fungal biodiversity in rhizosphere of healthy and needle cast-affected Scots pine transplants
}

\author{
MAŁGORZATA MAŃKA \\ Department of Forest Pathology, The August Cieszkowski Agricultural University \\ Wojska Polskiego 71c, PL-60-625 Poznań, mmanka@au.poznan.pl
}

Mańk a M.: Fungal biodiversity in rhizosphere of healthy and needle cast-affected Scots pine transplants. Acta Mycol. 42 (2): 199-202, 2007.

Healthy Scots pine (Pinus sylvestris L.) transplants had in rhizosphere a community of saprotrophic fungi which considerably suppressed the growth of severe root pathogens Heterobasidion annosum and Armillaria obscura. A community from transplants affected by needle cast (Lophodermium spp.) suppressed both pathogens to a much smaller extent.

Key words: Scots pine, rhizosphere fungi, needle-cast, Heterobasidion, Armillaria

\section{INTRODUCTION}

Fungi in the soil environment of host-plant may reflect the probable effect of the environment they derive from, on a pathogen's activity towards its host-plant (Mańka K. 1990). Communities of fungi from rhizosphere of Scots pine (Pinus sylvestris L.) transplants can effect growth of root pathogenic fungi in various ways, depending on year, season of the year and transplant's age (Mańka K. et al. 1993; Mańka M. 1995b).

The aim of the work was to investigate the influence of needle cast attack on Scots pine transplants rhizosphere fungi communities, and on the communities' effect on growth of severe root pathogens Heterobasidion annosum (Fr.) Bref. and Armillaria obscura (Schaeff.) Herink.

\section{MATERIALS AND METHODS}

In Konstantynowo forest nursery (near Poznań) 2-year-old Scots pine (P. sylvestris) transplants (sown in April 1992, on deep sandy forest soil) grew in two groups: well developed healthy ones, and poorly developed needle cast-affected (Lophodermium spp.) ones. On April 18, 1994, rhizosphere soil from both groups was sampled by shaking off (Mańka K., Mańka M. 1993) and communities of soil fungi were isolated according to Warcup's soil plate method modified by K. Mańka (Warcup 
1950; Mańka K. 1964; Johnson, Mańka K. 1961; Mańka K., Salmanowicz 1987). The 2 communities (with specific structure and function) were considered characteristic of the rhizosphere soils investigated. Both communities were tested for their effect on growth of $H$. annosum type $\mathrm{P}$ and $A$. obscura with the biotic series method by K. Mańka (Mańka K. 1974; Mańka K., Mańka M. 1992; Mańka M. 1995a). The test was performed on PDA for H. annosum (biotic effect estimated after 10 days) and on malt agar for $A$. obscura (biotic effect estimated after 20 days).

The biotic test resulted in describing the phytopathological function of both communities. The function is expressed by summary biotic effect (SBE), i.e. the effect of the entire soil fungi community on the pathogen's growth. The SBE results from summarizing all the general biotic effects $(\mathrm{GBE}=$ an effect of all the isolates of a species on the pathogen's growth). A GBE results from multiplying frequency of the species by individual biotic effect (IBE) value, that is the effect of one isolate of the given species on the pathogen's growth.

Any of the biotic effects may be positive (indicating suppressive effect on the pathogen's growth), negative (indicating supporting effect on the pathogen's growth) or neutral ("0"). Intensity of the supporting/suppressing effect is described by the absolute value of the effect.

\section{RESULTS AND DISCUSSION}

The fungal community from healthy transplants was more numerous (by $28 \%$, Tabs 1 and 2) than the community from the needle cast-affected ones. The species composition was not very different. The most remarkable difference was to be seen in Trichoderma spp. - there were all together 41 isolates of T. koningii and T. longibrachiatum in the community from healthy transplants, and only 8 isolates of $T$. viride in the community from diseased ones (Tabs 1 and 2).

An interesting phenomenon was observed: representatives of the same species happened to behave variously, with respect to a pathogen, depending on from what community they derived. Their individual biotic effect (IBE) supported the pathogen to a greater extent, when they were isolated from diseased plant rhizosphere. It was most evident in Coniothyrium fuckelii, which had a very suppressing effect on H. annosum when isolated from healthy pine rhizosphere (IBE +10, Tab. 1), and a slightly supporting effect when isolated from diseased pine rhisosphere (IBE -2, Tab. 2). The same was true for Umbelopsis vinacea with IBE -2 and -5, and Fusarium oxysporum with IBE +3 and 0 , when derived from healthy and diseased plants, respectively.

All the summary biotic effects (SBE) exerted by the rhizosphere fungi communities on both pathogens were positive, which means that the growth of both pathogens was suppressed by both communities. The suppression of $H$. annosum was much bigger in rhizosphere of healthy pine seedlings (SBE +1342 , Tab. 1) than of diseased seedlings (SBE +236, Tab. 2).

The situation was similar with respect to $A$. obscura - the rhizosphere fungi community from healthy pine seedlings had SBE +721 (Tab. 1), and from diseased ones $-\mathrm{SBE}+443$ (Tab. 2). This may mean that the needle cast contributed not only to worse development of Scots pine transplants but also to formation in their rhizosphere of a fungal community that could suppress both pathogens in question to a 
Table 1

Biotic effect of rhizosphere fungi communities from healthy 2-year-old Scots pine transplants on the growth of Heterobasidion annosum and Armillaria obscura

\begin{tabular}{|c|c|c|c|c|c|}
\hline \multirow{3}{*}{ Species of fungi } & \multirow{3}{*}{$\begin{array}{c}\text { Fre- } \\
\text { quency }\end{array}$} & \multicolumn{4}{|c|}{ Biotic effects on } \\
\hline & & \multicolumn{2}{|c|}{$\begin{array}{c}\text { Heterobasidion } \\
\text { annosum }\end{array}$} & \multicolumn{2}{|c|}{ Armillaria obscura } \\
\hline & & IBE & GBE & IBE & GBE \\
\hline Umbelopsis vinacea (Dixon-Stew.) Arx & 59 & -2 & -118 & +2 & +118 \\
\hline Paecilomyces marquandii (Masee) Hug. & 52 & +6 & +312 & +1 & +52 \\
\hline Coniothyrium fuckelii Sacc. & 48 & +10 & +480 & 0 & 0 \\
\hline Trichoderma koningii Oudem. & 36 & +8 & +288 & +8 & +288 \\
\hline Penicillium daleae Zaleski & 26 & +3 & +78 & +1 & +26 \\
\hline Penicillium sp. 1 & 21 & +6 & +126 & +4 & +84 \\
\hline Truncatella truncata (Lév.) Steyaert & 15 & 0 & 0 & +4 & +60 \\
\hline Penicillium steckii Zaleski & 7 & +13 & +91 & 0 & 0 \\
\hline Fusarium oxysporum Schlecht. & 7 & +3 & +21 & +4 & +28 \\
\hline Trichoderma longibrachiatum Rifai & 5 & +8 & +40 & +8 & +40 \\
\hline Chaetomium aureum Chivers & 5 & +3 & +15 & +3 & +15 \\
\hline Penicillium brevicompactum Dierckx & 3 & +1 & +3 & 0 & 0 \\
\hline Dematiaceae sp. 1 & 2 & -4 & -8 & +1 & +2 \\
\hline Zygorhynchus moellerii Vuill. & 2 & +7 & +14 & +4 & +8 \\
\hline Summary biotic effect & 288 & & +1342 & & +721 \\
\hline
\end{tabular}

Explanations: IBE - individual biotic effect; GBE - general biotic effect; SBE - summary biotic effect.

Table 2

Biotic effect of rhizosphere fungi communities from needle cast-affected 2-year-old Scots pine transplants on the growth of Heterobasidion annosum and Armillaria obscura

\begin{tabular}{|c|c|c|c|c|c|}
\hline \multirow{3}{*}{ Species of fungi } & \multirow{3}{*}{$\begin{array}{c}\text { Fre- } \\
\text { quency }\end{array}$} & \multicolumn{4}{|c|}{ Biotic effects on } \\
\hline & & \multicolumn{2}{|c|}{$\begin{array}{l}\text { Heterobasidion } \\
\text { annosum }\end{array}$} & \multicolumn{2}{|c|}{ Armillaria obscura } \\
\hline & & IBE & GBE & IBE & GBE \\
\hline Coniothyrium fuckelii Sacc. & 55 & -2 & -110 & 0 & 0 \\
\hline Penicillium sp. 2 & 34 & +12 & +408 & -1 & -34 \\
\hline Umbelopsis vinacea (Dixon-Stew.) Arx & 33 & -5 & -165 & 0 & 0 \\
\hline Penicillium sp. 3 & 31 & 0 & 0 & +6 & +186 \\
\hline Chaetomium aureum Chivers & 17 & 0 & 0 & +4 & +68 \\
\hline Truncatella truncata (Lév.) Steyaert & 15 & -1 & -15 & +4 & +60 \\
\hline Penicillium nigricans Bainier ex Thom & 9 & +4 & +36 & +5 & +45 \\
\hline Chaetomium globosum Kunze ex Steud. & 8 & +2 & +16 & 0 & 0 \\
\hline Trichoderma viride Pers. ex Gray & 8 & +8 & +64 & +7 & +56 \\
\hline Penicillium sp. 4 & 5 & -5 & -25 & +6 & +30 \\
\hline Fusarium oxysporum Schlecht. & 5 & 0 & 0 & +4 & +20 \\
\hline Zygorhynchus moellerii Vuill. & 3 & +7 & +21 & +5 & +15 \\
\hline Penicillium verruculosum Dierckx & 2 & +3 & +6 & -1 & -3 \\
\hline Summary biotic effect & 225 & & +236 & & +443 \\
\hline
\end{tabular}

Legend - see Tab. 1

smaller extent, than the fungal community in the rhizosphere of healthy transplants. It seems that the needle cast, being a disease of the over ground part of the plant, may considerably influence biotic relations in soil. 


\section{CONCLUSION}

The Scots pine transplants affected by needle cast should not be used for establishing plantations not only because of their poor development and poor growth prospects (which is obvious), but also because they are not able to resist soil-borne pathogenic fungi to an extent comparable to healthy transplants.

\section{REFERENCES}

Johnson L. F., Mańka K. 1961. A modification of Warcup's soil plate method for isolating soil fungi. Soil Science 2: 79-83.

Ma ń k a K. 1964. Próby dalszego udoskonalenia zmodyfikowanej metody Warcupa izolowania grzybów z gleby. PTPN, Prace Kom. Nauk Rol. i Kom. Nauk Leś. 17: 29-43.

M a ń k a K. 1974. Zbiorowiska grzybów jako kryterium oceny wpływu środowiska na choroby roślin. Zesz. Probl. Post. Nauk Rol. 160: 9-23.

Mań k a K. 1990. Saprofityczna mikoflora środowiska glebowego a zdrowotność roślin. Phytopathol. Pol. 11: $122-133$.

Mań ka K., S a lm a n ow icz B. 1987. Udoskonalenie niektórych technik zmodyfikowanej metody płytek glebowych do izolowania grzybów z gleby z punktu widzenia potrzeb mikologii fitopatologicznej. Rocz. Nauk Rol., Seria E 17 (1): 35-46.

Mańka K., Mańka M. 1992. A new method for evaluating interaction between soil inhabiting fungi and plant pathogens. IOBC/WPRS Bulletin 15 (1): 73-75.

Mańka K., Mańk a M. 1993. O metodzie izolacji grzybów z ryzosfery drzew leśnych. Materiały z IV Konferencji Sekcji Biologicznych Metod Ochrony Roślin przed Chorobami, $22-2304$ 1993, PTFit., Skierniewice: 3-7.

Mańka K., Mańka M., Kwaśna H., Łakomy P., Babkiewicz M. 1993. Zagrożenie sadzonek drzew leśnych przez patogeny korzeni a zbiorowiska grzybów ryzosferowych. Materiały z IV Konferencji Sekcji Biologicznych Metod Ochrony Roślin przed Chorobami, 22-23.04.1993, PTFit., Skierniewice: $7-13$.

Mańka M. 1995 a. Non-pathogenic soil fungi reflecting soil environment. (In:) M. Mańka (ed.). Environmental Biotic Factors In Integrated Plant Disease Control, Proceedings of 3rd Conference of European Foundation for Plant Pathology, September 5-9, 1994, Poznań: 27-36.

Mańka M. 1995 b. Effect of rhizosphere fungi communities from Scots pine and birch transplants on growth of root pathogenic fungi. (In:) L.B. Orlik owski, Cz. Sk rzy pczak (eds). Biological control of soil-borne and postharvest pathogens. The Polish Phytopathological Society, Section of Biological Control of Plant Diseases, Research Institute of Pomology and Floriculture, Skierniewice: 61-64.

Warcup J. H. 1950. The soil plate method for isolation of fungi from soil. Nature 166: 117-118.

\section{Bioróżnorodność grzybów z ryzosfery zdrowych i porażonych przez osutkę sadzonek sosny zwyczajnej}

\section{Streszczenie}

Porównano zbiorowiska grzybów ryzosferowych dwuletnich sadzonek sosny zwyczajnej: zdrowych i dorodnych oraz niewyrośniętych, porażonych przez osutkę (Lophodermium spp.). Zbiorowisko grzybów ze zdrowych sadzonek sosny ograniczało wzrost patogenów korzeni Heterobasidion annosum i Armillaria obscura znaczniej bardziej niż zbiorowisko z porażonych przez osutkę sadzonek.

Sadzonki porażone przez osutkę nie nadają się do wysadzania na uprawy leśne nie tylko ze względu na zahamowanie wzrostu i ograniczony przez chorobę aparat asymilacyjny, ale również z powodu tego, że ich zbiorowiska grzybów ryzosferowych nie są w stanie ograniczyć wzrostu patogenów obecnych w glebie leśnej w takim stopniu, jak zbiorowiska ryzosferowe zdrowych sadzonek. 